\title{
Feeding by the heterotrophic dinoflagellates Gyrodinium dominans and $G$. spirale on the red-tide dinoflagellate Prorocentrum minimum
}

\author{
Jae Seong Kim, Hae Jin Jeong* \\ School of Earth and Environmental Sciences, College of Natural Sciences, Seoul National University, Seoul 151-742, \\ South Korea
}

\begin{abstract}
To investigate the roles of Gyrodinium dominans and G. spirale, which have been reported to be abundant heterotrophic dinoflagellates in many coastal waters at different stages of red tides dominated by the dinoflagellate Prorocentrum minimum, we measured their growth and ingestion rates when feeding on $P$. minimum and calculated grazing coefficients by combining field data on abundances of $G$. dominans, G. spirale, and co-occurring $P$. minimum with laboratory data on ingestion rates obtained in the present study. In addition, the grazing coefficients of G. dominans and G. spirale on $P$. minimum were compared to those for co-occurring copepods, Acartia spp. Specific growth rates of $G$. dominans and $G$. spirale increased rapidly with increasing mean prey concentration before saturating at the $P$. minimum concentrations of ca. 150 and $80 \mathrm{ng} \mathrm{C} \mathrm{ml}^{-1}$, respectively. The maximum specific growth rate of $G$. dominans on $P$. minimum $\left(1.13 \mathrm{~d}^{-1}\right)$ was higher than that of $G$.

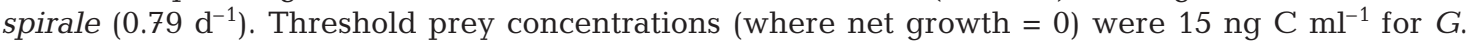
dominans and $23 \mathrm{ng} \mathrm{C} \mathrm{ml}^{-1}$ for $G$. spirale. Maximum ingestion and clearance rates of G. dominans on $P$. minimum (1.2 ng $\mathrm{C}$ grazer ${ }^{-1} \mathrm{~d}^{-1}$ and $0.9 \mu$ grazer $^{-1} \mathrm{~h}^{-1}$, respectively) were much lower than those of $G$. spirale on the prey (13.6 ng C grazer ${ }^{-1} \mathrm{~d}^{-1}$ and $5.3 \mu l$ grazer $^{-1} \mathrm{~h}^{-1}$, respectively). Calculated grazing coefficients for $G$. dominans on $P$. minimum (up to $0.066 \mathrm{~h}^{-1}$, i.e. $6.3 \%$ of $P$. minimum populations were removed by a $G$. dominans population in $1 \mathrm{~h}$ ) or those by $G$. spirale (up to $0.231 \mathrm{~h}^{-1}$, i.e. $39 \%$ of $P$. minimum populations were removed in $1 \mathrm{~h}$ ) were much higher than those for co-occurring Acartia spp. (up to $0.001 \mathrm{~h}^{-1}$, i.e. $0.1 \%$ of $P$. minimum populations were removed by Acartia spp. populations in $1 \mathrm{~h}$ ). The results of the present study suggest that $G$. dominans and/or G. spirale sometimes have considerable grazing impacts on populations of $P$. minimum and are the most effective zooplanktonic grazers on the prey.
\end{abstract}

KEY WORDS: Copepod · Food web · Harmful algal bloom · Ingestion $\cdot$ Mixotroph $\cdot$ Protist

\section{INTRODUCTION}

Dinoflagellate blooms, often referred to as red tides, can alter the balance of food webs and cause largescale mortalities of fish and shellfish (ECOHAB 1995). Studies of red-tide formation and persistence suggest that grazing pressure may play an important role in bloom dynamics (Watras et al. 1985). In particular, grazing by microzooplankton is believed to contribute to the decline of red tides (Holmes et al. 1967, Eppley \&
Harrison 1975, Jeong 1995). Prorocentrum minimum is a common mixotrophic dinoflagellate which often forms red tides in the waters off many countries (Trigueros \& Orive 2000, Yallop 2001, Gallegos \& Jordan 2002). A few heterotrophic protistan grazers have been reported to grow on $P$. minimum; the large ciliates Strombidinopsis sp., Favella taraikaensis, and F. ehrenbergii are known to grow on $P$. minimum (Stoecker et al. 1981, Taniguchi \& Kawakami 1985, Jeong et al. 1999), but common heterotrophic dino- 
flagellate Polykrikos kofoidii and the ciliate protostomid Tiarina fusus do not grow on this dinoflagellate prey (Jeong et al. 2001, 2002).

Heterotrophic dinoflagellates are ubiquitous protists in marine environments and play diverse ecological roles in the marine planktonic community (Lessard 1991, Jeong 1999, Sherr \& Sherr 2000, Tillmann \& Reckermann 2002). The heterotrophic dinoflagellates Gyrodinium spp. are ubiquitous and often abundant in many coastal waters (e.g. Haigh \& Taylor 1991), in particular, during red tides dominated by Prorocentrum minimum (Sournia et al. 1991, Borkman et al. 1993, Fiala et al. 1998, Hori et al. 1998, Johnson et al. 2003). High abundance of Gyrodinium spp. during red tides dominated by $P$. minimum suggests that these grazers may grow well on $P$. minimum and have a considerable grazing impact on the populations of $P$. minimum. Hansen (1992) reported on the growth rate of G. spirale on $P$. minimum. However, no study has reported growth and grazing rates of Gyrodinium spp. on $P$. minimum as a function of prey concentration, and few studies have estimated their grazing impact on the prey (Johnson et al. 2003).

To understand the role of Gyrodinium spp. in the dynamics of Prorocentrum minimum, we established a monoclonal culture of G. dominans and G. spirale and conducted experiments to examine its numerical and functional responses when grazing on $P$. minimum. We also estimated the grazing coefficients attributable to Gyrodinium spp. feeding on $P$. minimum by combining field data on the abundances of G. dominans, G. spirale, and co-occurring $P$. minimum with laboratory data on the ingestion rates obtained in the present study.

Maximum growth and grazing rates of Gyrodinium dominans and G. spirale on Prorocentrum minimum are compared with those of heterotrophic dinoflagellates and ciliates feeding on the same prey species, and grazing coefficients attributable to Gyrodinium spp. on $P$. minimum were compared with those of the copepods. Results of the present study provide a basis for understanding the potential of Gyrodinium spp. to influence the population dynamics of $P$. minimum.

\section{MATERIALS AND METHODS}

Culture of phytoplankton prey. Prorocentrum minimum (PMJH00) was grown at $20^{\circ} \mathrm{C}$ in enriched $\mathrm{f} / 2$ seawater media (Guillard \& Ryther 1962) without silicate, with continuous illumination at $100 \mu \mathrm{E} \mathrm{m} \mathrm{m}^{-2} \mathrm{~s}^{-1}$ provided by cool white fluorescent lights. Only cultures in an exponential growth phase were used for feeding experiments. The carbon content for this dinoflagellate $\left(0.15 \mathrm{ng} \mathrm{C}\right.$ cell $\left.^{-1}, \mathrm{n}>2000\right)$ was esti- mated from cell volume $(1100 \mu \mathrm{m})$ according to Strathmann (1967).

Isolation and culture of Gyrodinium spp. Plankton samples collected with water samplers were taken from coastal waters off Masan, Korea, during April 2003, when the water temperature and salinity were $18.5^{\circ} \mathrm{C}$ and $25 \mathrm{psu}$, respectively. The samples were screened gently through a $154 \mu \mathrm{m}$ Nitex mesh and placed in 6-well tissue culture plates, and a monoclonal culture of Gyrodinium dominans (or G. spirale) was established by 2 serial single-cell isolations. As the concentration of G. dominans (or G. spirale) feeding on Prorocentrum minimum increased, the grazers were subsequently transferred to 32,270 , and $500 \mathrm{ml}$ polycarbonate $(\mathrm{PC})$ bottles containing fresh $P$. minimum. The bottles were again filled to capacity with freshly filtered seawater, capped, and placed on a rotating wheel at $0.9 \mathrm{rpm}$ at $20^{\circ} \mathrm{C}$ at $10 \mu \mathrm{E} \mathrm{m} \mathrm{m}^{-2}$ of cool white fluorescent light on a 12:12 h light:dark cycle. Once dense cultures of Gyrodinium spp. were obtained, they were transferred to $500 \mathrm{ml}$ PC bottles of fresh prey every $2 \mathrm{~d}$. Experiments were conducted when large volumes of Gyrodinium spp. culture were available. The carbon contents for $G$. dominans and G. spirale were estimated from cell volume (see next subsection) according to Menden-Deuer \& Lessard (2000).

Cell volume. Cell length and maximum width of Gyrodinium dominans and G. spirale preserved in 5\% acid Lugol's solution were measured using a compound or inverted microscope. The shapes of these Gyrodinium species were estimated as 2 cones joined at the cell equator (= maximum width of the cell). Cell volumes of both preserved Gyrodinium species were calculated according to the equation: volume $=$ $1 / 3\left[\pi(\text { cell width } / 2)^{2}\right]$ (cell length).

Swimming speed. Swimming speeds of Gyrodinium dominans and G. spirale starved for $12 \mathrm{~h}$ were measured at $20^{\circ} \mathrm{C}$ using a video-analysis system. For each species, aliquots from a dense culture were added to multiwell plates and allowed to acclimatize for $30 \mathrm{~min}$. Swimming was then observed and recorded at $40 \times$, with mean and maximum swimming velocity analyzed for fast-swimming cells that exhibited linear paths. Average swimming speed was calculated based on the linear displacement of cells in $1 \mathrm{~s}$ during single-frame playback. Swimming speeds of 30 cells for each Gyrodinium species were measured.

Growth and ingestion rates. Expts 1 and 2 were designed to measure growth, ingestion, and clearance rates of Gyrodinium dominans and G. spirale, respectively, as a function of the prey concentration, when feeding on Prorocentrum minimum (Table 1).

One or $2 \mathrm{~d}$ before these experiments were conducted, dense cultures of Gyrodinium dominans (or 
G. spirale) grazing on Prorocentrum minimum were transferred into 11 PC bottles containing low concentrations of the target prey. This was done to acclimatize the grazer to the target prey and minimize possible residual growth resulting from the ingestion of prey during batch culture. The bottles were filled to capacity with filtered seawater and placed on a rotating wheel to incubate as above. The abundances of $G$. dominans (or G. spirale) and prey were determined by enumerating cells in three $1 \mathrm{ml}$ Sedgwick-Rafter counting chambers (SRCs).

The initial concentrations of Gyrodinium dominans (or G. spirale) and target prey were established using an autopipette to deliver predetermined volumes of known cell concentrations to the bottles. Triplicate $80 \mathrm{ml}$ PC experiment bottles (mixtures of predator and prey) and triplicate control bottles (prey only) were set up for each predator-prey combination. Triplicate control bottles containing only $G$. dominans (or G. spirale) were also established at 1 predator concentration. Ten $\mathrm{ml}$ of $\mathrm{f} / 2$ medium were added to all bottles, which were then filled to capacity with freshly filtered seawater and capped. To determine actual predator and prey concentrations at the beginning of the experiment and after 24, 48, and $72 \mathrm{~h}$ incubation, a $5 \mathrm{ml}$ aliquot for $G$. dominans (10 $\mathrm{ml}$ aliquot for G. spirale) was removed from each bottle and fixed with $5 \%$ acid Lugol's solution, and all predator cells and all or $>200$ prey cells in three $1 \mathrm{ml}$ SRCs were enumerated. Prior to taking subsamples, the condition of G. dominans (or G. spirale) and its prey was assessed using a dissecting microscope. The bottles were filled again to capacity with freshly filtered seawater, capped, and placed on rotating wheels under the environmental conditions described above. Dilution of the cultures associated with refilling the bottles was considered in calculating growth and ingestion rates.

The specific growth rate of Gyrodinium dominans (or G. spirale) $\left(\mu, \mathrm{d}^{-1}\right)$, was calculated by averaging the

Table 1. Design of experiments. Values in prey and predator columns represent actual initial concentrations (cells $\mathrm{ml}^{-1}$ ) followed by calculated carbon biomass (ng $\mathrm{C} \mathrm{ml}^{-1}$ ) in parentheses. Concentrations of Gyrodinium dominans and $G$. spirale in control bottles were 92 (Expt 1) and 45 cells ml$^{-1}$ (Expt 2), respectively

\begin{tabular}{|c|c|c|c|}
\hline \multirow[t]{2}{*}{ Expt } & \multicolumn{2}{|c|}{ Predator } & \multirow{2}{*}{$\begin{array}{c}\text { Prey } \\
\text { Concentration }\end{array}$} \\
\hline & Species & Concentration & \\
\hline 1 & Gyrodinium dominans & $7.6-136.2$ & $\begin{array}{c}108(16), 200(30) \\
507(76), 983(148) \\
2955(443), 7220(1083) \\
18608(2791)\end{array}$ \\
\hline 2 & Gyrodinium spirale & $7.3-46.4$ & $\begin{array}{c}99(15), 167(25), 413(62) \\
1139(171), 3831(571), \\
6227(934), 12416(1861)\end{array}$ \\
\hline
\end{tabular}

instantaneous growth rates (IGR) for each sampling interval, calculated as:

$$
\operatorname{IGR}=\frac{\operatorname{Ln}\left(S_{t_{2}} / S_{t_{1}}\right)}{t_{2}-t_{1}} \times 24
$$

where $S_{t_{1}}$ and $S_{t_{2}}$ are the concentrations of Gyrodinium spp. at consecutive samplings. The final values of $t_{2}$ for calculation were $24 \mathrm{~h}$ for $G$. spirale and $48 \mathrm{~h}$ for G. dominans, which provided the highest specific growth rate. After $24 \mathrm{~h}$, prey concentrations for $G$. spirale had already been largely reduced (ca. 35 to $75 \%$ of the initial concentrations).

Data for Gyrodinium growth rate were fitted to a Michaelis-Menten equation:

$$
\mu=\frac{\mu_{\max }\left(x-x^{\prime}\right)}{K_{\mathrm{GR}}+\left(x-x^{\prime}\right)}
$$

where $\mu_{\max }$ is the maximum growth rate $\left(\mathrm{d}^{-1}\right) ; x$ is the prey concentration (cells $\mathrm{ml}^{-1}$ or $\mathrm{ng} \mathrm{C} \mathrm{ml}^{-1}$ ), $\mathrm{x}^{\prime}$ is the threshold prey concentration (the prey concentration where $\mu=0$ ), and $K_{\mathrm{GR}}$ is the the prey concentration sustaining $1 / 2 \mu_{\max }$. Data were iteratively fitted to the model using DeltaGraph ${ }^{\circledR}$ (Delta Point).

Ingestion and clearance rates were calculated using the equations of Frost (1972) and Heinbokel (1978). Incubation time for calculating ingestion and clearance rates was the same as for estimating growth rate. Ingestion rate data for Gyrodinium dominans were fitted to a linear regression equation, and those for $G$. spirale to a Michaelis-Menten equation:

$$
\mathrm{IR}=\frac{I_{\max }(x)}{K_{\mathrm{IR}}+(x)}
$$

where $I_{\max }$ is the maximum ingestion rate (cells Gyrodinium $^{-1} \mathrm{~d}^{-1}$ or ng $C$ Gyrodinium $\left.{ }^{-1} \mathrm{~d}^{-1}\right), x$ is the prey concentration (cells $\mathrm{ml}^{-1}$ or $\mathrm{ng} \mathrm{C} \mathrm{ml} \mathrm{Cl}^{-1}$ ), and $K_{\mathrm{IR}}$ is the prey concentration sustaining $1 / 2 I_{\max }$.

Gross growth efficiency. Gross growth efficiency (GGE), defined as grazer biomass produced (+) or lost (-) per prey biomass ingested, as a function of mean prey concentration, was calculated from estimates of carbon content per cell based on cell volume for each mean prey concentration.

Grazing impact. With some assumptions (see Table 2), we estimated grazing coefficients attributable to Gyrodinium spp. on Prorocentrum minimum by combining field data on abundances of Gyrodinium spp. and prey with ingestion rates of the predators on the prey obtained in the present study. For comparison (of the grazing coefficients between Gyrodinium spp. and the copepods Acartia 
spp. on $P$. minimum), we also estimated grazing coefficients attributable to co-occurring dominant copepods Acartia spp. on $P$. minimum by combining field data on abundances of Acartia spp. and P. minimum with ingestion rates of the grazer on the prey obtained from the equation of Besiktepe \& Dam (2002). The data on the abundances of $P$. minimum, Gyrodinium spp., and co-occurring Acartia spp. used in this estimation were obtained from water samples and net-towed samples collected from the coastal waters at the same stations off Kwangyang (in 2000) and Masan (in 2003), Korea.

Grazing coefficients $\left(g, \mathrm{~h}^{-1}\right)$ were calculated as:

$$
g=(1 / \Delta t) \ln \left[C_{\mathrm{i}} /\left(C_{\mathrm{i}}-C_{\mathrm{e}}\right)\right]
$$

where $\Delta t(\mathrm{~h})$ is a time interval, $C_{\mathrm{e}}\left(\right.$ cells $\left.\mathrm{ml}^{-1}\right)$ is the number of prey cells eaten by the Gyrodinium spp. (or Acartia spp.) population in $1 \mathrm{ml}$ of seawater in $1 \mathrm{~h}$, and $C_{\mathrm{i}}\left(\right.$ cells ml $\left.\mathrm{s}^{-1}\right)$ is the initial cell concentration of prey for a given hour. The values of $C_{\mathrm{e}}$ were calculated as:

$$
C_{\mathrm{e}}=\mathrm{PIR} \times 1 \mathrm{~h}=\mathrm{IR} \times G \times 1 \mathrm{~h}
$$

where PIR is the population ingestion rate of Gyrodinium spp. (or Acartia spp.) on Prorocentrum minimum in $1 \mathrm{ml}$ of seawater (prey eaten $\mathrm{ml}^{-1} \mathrm{~h}^{-1}$ ), IR is the ingestion rate (prey eaten grazer ${ }^{-1} \mathrm{~h}^{-1}$ ) of Gyrodinium spp. (or Acartia spp.) on $P$. minimum, and $G$ is the abundance (grazers $\mathrm{ml}^{-1}$ ) of Gyrodinium spp. (or Acartia spp.) at the same time as $C_{\mathrm{i}}$.

\section{RESULTS}

\section{Swimming speed}

Gyrodinium dominans swam faster than G. spirale. The average $( \pm \mathrm{SE}, \mathrm{n}=30)$ and maximum swimming speeds of $G$. dominans were $1463( \pm 78)$ and $2533 \mu \mathrm{m}$ $\mathrm{s}^{-1}$, respectively, while those of $G$. spirale were 815 $( \pm 54)$ and $1175 \mu \mathrm{m} \mathrm{s}^{-1}$, respectively.

\section{Growth rates}

Both Gyrodinium dominans and G. spirale grew well on Prorocentrum minimum. The specific growth rates of $G$. dominans feeding on a unialgal diet of P. minimum increased with increasing mean prey concentration up to ca. $150 \mathrm{ng} \mathrm{C} \mathrm{ml}^{-1}$, but were saturated at higher prey concentrations (Fig. 1). When the data were fitted to Eq. (2), the maximum specific growth rate $\left(\mu_{\max }\right)$ of $G$. dominans was $1.13 \mathrm{~d}^{-1}$. A threshold prey concentration (where net growth $=0$ ) for G. dominans was $14.7 \mathrm{ng} \mathrm{C} \mathrm{ml}^{-1}$ (98 cells ml- ${ }^{-1}$ ).

The specific growth rates of Gyrodinium spirale feeding on a unialgal diet of Prorocentrum minimum increased with increasing mean prey concentration up to ca. $80 \mathrm{ng} \mathrm{C} \mathrm{ml}^{-1}$, but were saturated at higher prey concentrations (Fig. 2). When the data were fitted to Eq. (2), $\mu_{\max }$ of G. spirale was $0.786 \mathrm{~d}^{-1}$. A threshold

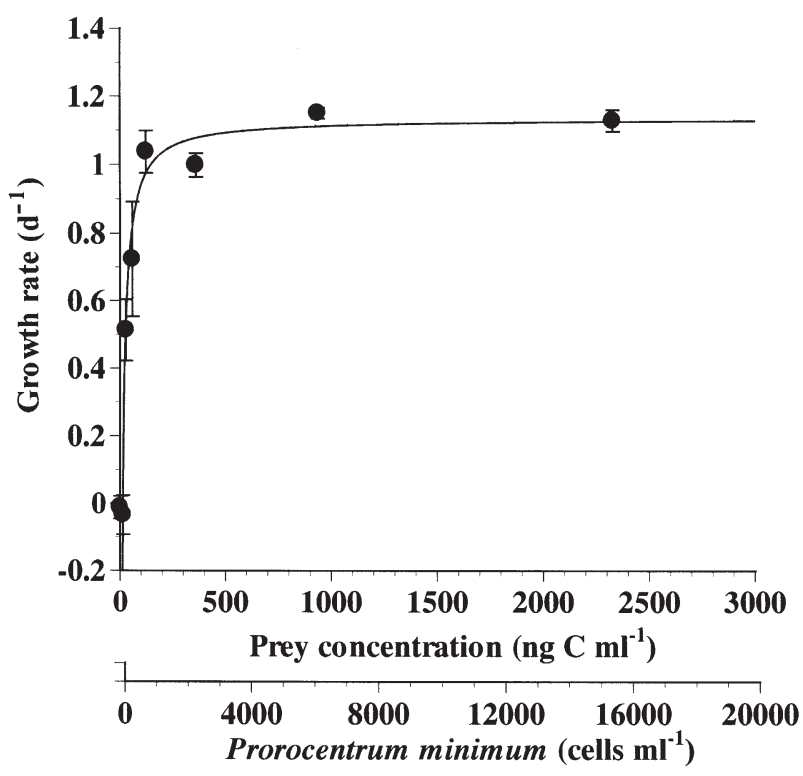

Fig. 1. Gyrodinium dominans. Specific growth rates on Prorocentrum minimum as a function of mean prey concentration $(x)$. Symbols represent treatment means \pm 1 SE. The curve is fitted by a Michaelis-Menten equation (Eq. 2) using all treatments in the experiment. Growth rate $\left(\mathrm{GR}, \mathrm{d}^{-1}\right)=1.13\{(x-$ $14.7) /[18.1+(x-14.7)]\}, \mathrm{r}^{2}=0.915$

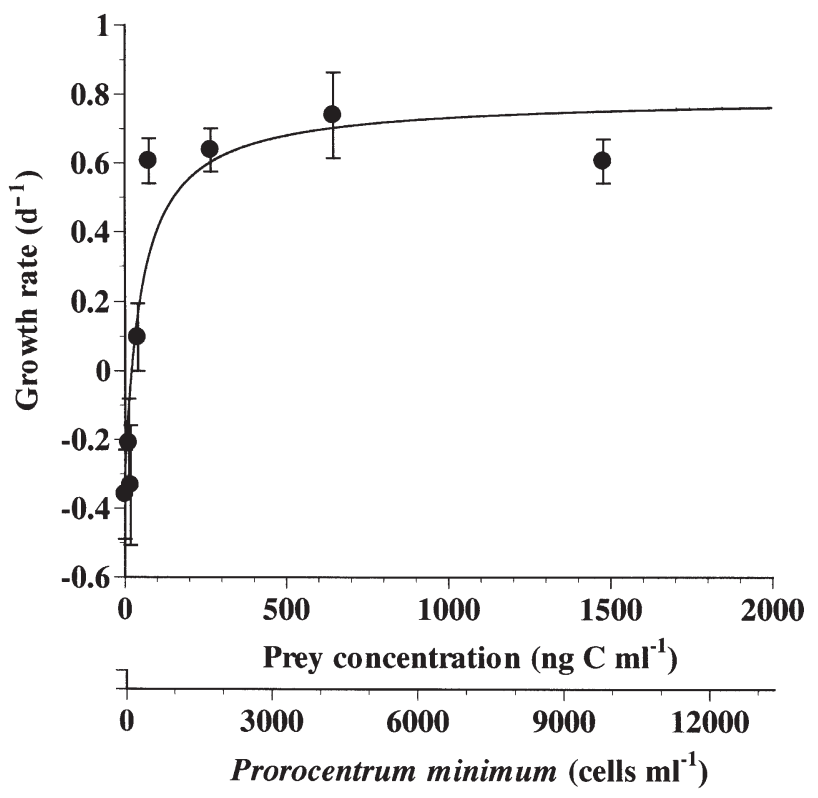

Fig. 2. Gyrodinium spirale. Specific growth rates on Prorocentrum minimum as a function of mean prey concentration $(x)$. Symbols and curve as in Fig. 1. Growth rate $\left(G R, d^{-1}\right)=$ $0.786\{(x-22.8) /[73.8+(x-22.8)]\}, \mathrm{r}^{2}=0.784$ 


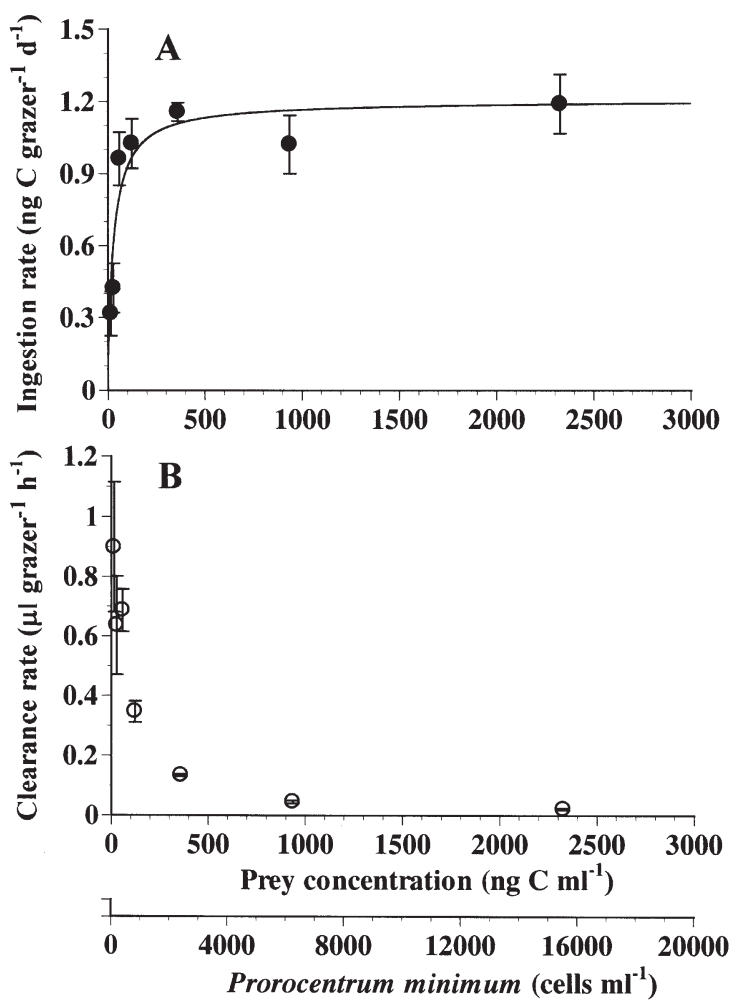

Fig. 3. Gyrodinium dominans. (A) Ingestion and (B) clearance rates on Prorocentrum minimum as a function of mean prey concentration $(x)$. Symbols and curve as in Fig. 1. Ingestion rate $\left(\mathrm{IR}, \mathrm{ng} \mathrm{C}\right.$ grazer $\left.^{-1} \mathrm{~d}^{-1}\right)=1.2[\mathrm{x} /(30.6+\mathrm{x})], \mathrm{r}^{2}=0.751$

prey concentration (where net growth $=0$ ) for G. spirale was $22.8 \mathrm{ng} \mathrm{C} \mathrm{ml}^{-1}\left(152\right.$ cells $\left.\mathrm{ml}^{-1}\right)$.

\section{Ingestion and clearance rates}

The ingestion rates of Gyrodinium dominans on a unialgal diet of Prorocentrum minimum increased with increasing mean prey concentration up to ca. $400 \mathrm{ng} \mathrm{C}$ $\mathrm{ml}^{-1}$, but were saturated at higher prey concentrations (Fig. 3A). When the data were fitted to Eq. (3), the maximum ingestion rate was $1.2 \mathrm{ng} \mathrm{C}$ grazer $^{-1} \mathrm{~d}^{-1}$ (8 prey cells grazer ${ }^{-1} \mathrm{~d}^{-1}$ ). The maximum clearance rate on Prorocentrum minimum was $0.9 \mu$ grazer $^{-1} \mathrm{~h}^{-1}$ (Fig. 3B), and the maximum volume-specific clearance rate was $1.5 \times 10^{6} \mathrm{~h}^{-1}$.

The ingestion rates of Gyrodinium spirale on a unialgal diet of Prorocentrum minimum continuously increased with increasing mean prey concentration (Fig. 4A). When the data were fitted to Eq. (3), the maximum ingestion rate was $13.6 \mathrm{ng} \mathrm{C}$ grazer $^{-1} \mathrm{~d}^{-1}(91$ prey cells grazer ${ }^{-1} \mathrm{~d}^{-1}$ ). The maximum clearance rates on Prorocentrum minimum were $5.3 \mu$ grazer $^{-1} \mathrm{~h}^{-1}$ (Fig. 4B), and the maximum volume-specific clearance rate was $6.5 \times 10^{5} \mathrm{~h}^{-1}$.
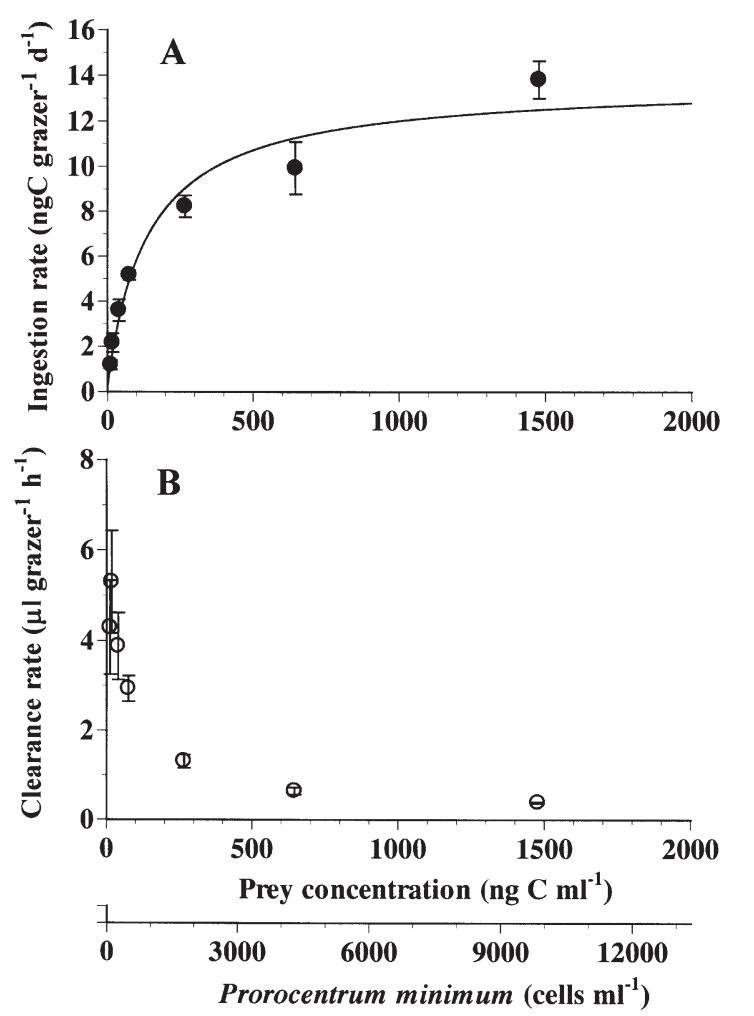

Fig. 4. Gyrodinium spirale. (A) Ingestion and (B) clearance rates on Prorocentrum minimum as a function of mean prey concentration $(x)$. Symbols and curve as in Fig. 1. Ingestion rate $\left(\mathrm{IR}, \mathrm{ng} \mathrm{C}\right.$ grazer $\left.^{-1} \mathrm{~d}^{-1}\right)=13.6[x /(137+x)], \mathrm{r}^{2}=0.917$

\section{Cell volume}

After $48 \mathrm{~h}$ incubation, the cell volume of Gyrodinium dominans fed Prorocentrum minimum at the lowest mean prey concentration of $16 \mathrm{ng} \mathrm{C} \mathrm{ml}^{-1}\left(590 \mathrm{\mu m}^{3}\right)$ was similar to that of $G$. dominans without added prey $\left(570 \mathrm{\mu m}^{3}\right)$, but at the higher prey concentration cell volume increased continuously from 860 to $1720 \mu^{3}$ with increasing mean prey concentration (Fig. 5A). The cell length distribution after $48 \mathrm{~h}$ incubation varied from a range of $13-20 \mu \mathrm{m}$ (mean $\pm \mathrm{SE}=17.9 \pm 0.5 \mu \mathrm{m})$ without added prey to $20-30 \mu \mathrm{m}$ (mean $\pm \mathrm{SE}=25.9 \pm$ $0.6 \mu \mathrm{m})$ at the highest mean prey concentration.

After $24 \mathrm{~h}$ incubation, the cell volume of Gyrodinium spirale fed Prorocentrum minimum at the lowest mean prey concentration of $11 \mathrm{ng} \mathrm{C} \mathrm{ml}^{-1}\left(8000 \mu^{3}\right)$ was larger than that of $G$. dominans without added prey $\left(5890 \mu \mathrm{m}^{3}\right)$, and at the higher prey concentration cell volume increased continuously from 8110-16860 $\mu^{3}$ with increasing mean prey concentration (Fig. 5B). The cell length distribution after $24 \mathrm{~h}$ incubation varied from a range of 58-71 $\mu \mathrm{m}$ (mean $\pm \mathrm{SE}=63.6 \pm 1.5)$ without added prey to $65-90 \mu \mathrm{m}$ (mean $\pm \mathrm{SE}=72.3 \pm 1.3$ ) at the highest mean prey concentration. 


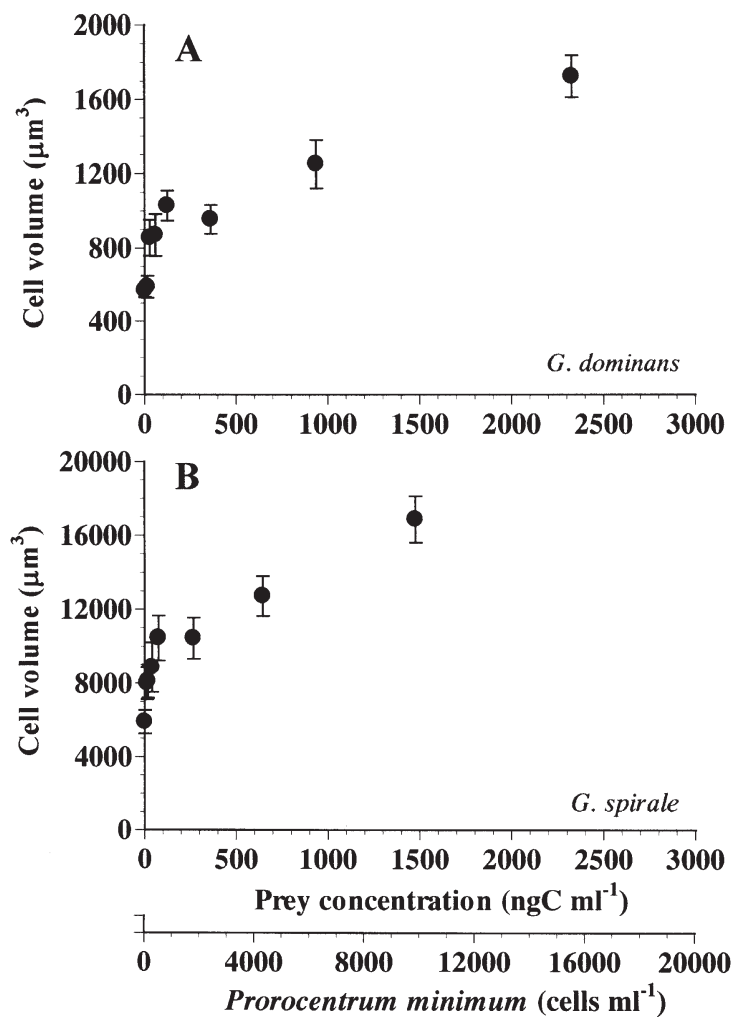

Fig. 5. (A) Gyrodinium dominans and (B) G. spirale. Cell volume of dinoflagellates fed Prorocentrum minimum as a function of mean prey concentration. Symbols represent treatment means $\pm 1 \mathrm{SE}$

The cell volumes of Gyrodinium dominans and $G$. spirale where maximum volume-specific clearance rate were obtained were 590 and $8110 \mu^{3}$, respectively.

\section{Gross growth efficiency}

GGEs of Gyrodinium dominans on Prorocentrum minimum were negative at the mean prey concentration of $16 \mathrm{ng} \mathrm{C} \mathrm{ml}^{-1}$, but increased up to $41 \%$ with increasing mean prey concentration (Fig. 6A).

GGEs of Gyrodinium spirale on Prorocentrum minimum were negative at the mean prey concentration of $17 \mathrm{ng} \mathrm{C} \mathrm{ml}^{-1}$, increased up to $17 \%$ at $75 \mathrm{ng} \mathrm{C} \mathrm{ml}^{-1}$, but were saturated at the higher prey concentrations (Fig. 6B).

\section{Grazing impact}

Grazing coefficients attributable to Gyrodinium dominans on co-occurring Prorocentrum minimum in the coastal waters off Kwangyang and Masan were 0

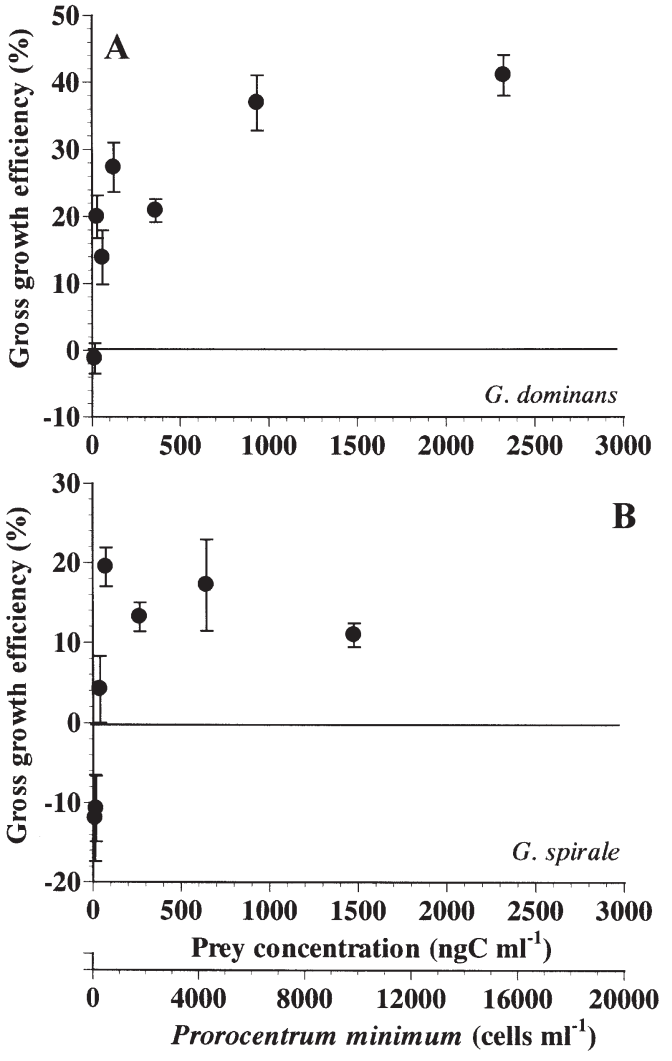

Fig. 6. (A) Gyrodinium dominans; (B) G. spirale. Gross growth efficiency (GGE), defined as Gyrodinium biomass produced (+) or lost (-) per Prorocentrum minimum biomass ingested, as a function of mean prey concentration. Symbols represent treatment means $\pm 1 \mathrm{SE}$

to $0.066 \mathrm{~h}^{-1}$, while those for G. spirale were 0 to $0.231 \mathrm{~h}^{-1}$ (i.e. up to $39 \%$ of $P$. minimum populations were removed by a $G$. spirale population in $1 \mathrm{~h}$ ) (Fig. 7A,B, Table 2). Grazing coefficients attributable to $G$. dominans plus $G$. spirale at the $P$. minimum concentrations of 60 to 300 cells ml $\mathrm{m}^{-1}\left(0.027\right.$ to $\left.0.296 \mathrm{~h}^{-1}\right)$ were much higher than those at the lower or higher $P$. minimum concentrations ( 0 to $\left.0.01 \mathrm{~h}^{-1}\right)$. Grazing coefficients attributable to co-occurring Acartia spp. on $P$. minimum were 0 to $0.001 \mathrm{~h}^{-1}$ (Fig. $7 \mathrm{C}$, Table 2).

\section{DISCUSSION}

\section{Protistan predators on Prorocentrum minimum}

Both Gyrodinium dominans and G. spirale grew well on Prorocentrum minimum in the present study. The heterotrophic dinoflagellates Oblea rotunda and Polykrikos kofoidii have been known not to grow on $P$. minimum (Strom \& Buskey 1993, Jeong et al. 2001). The heterotrophic dinoflagellates Protoperidinium 

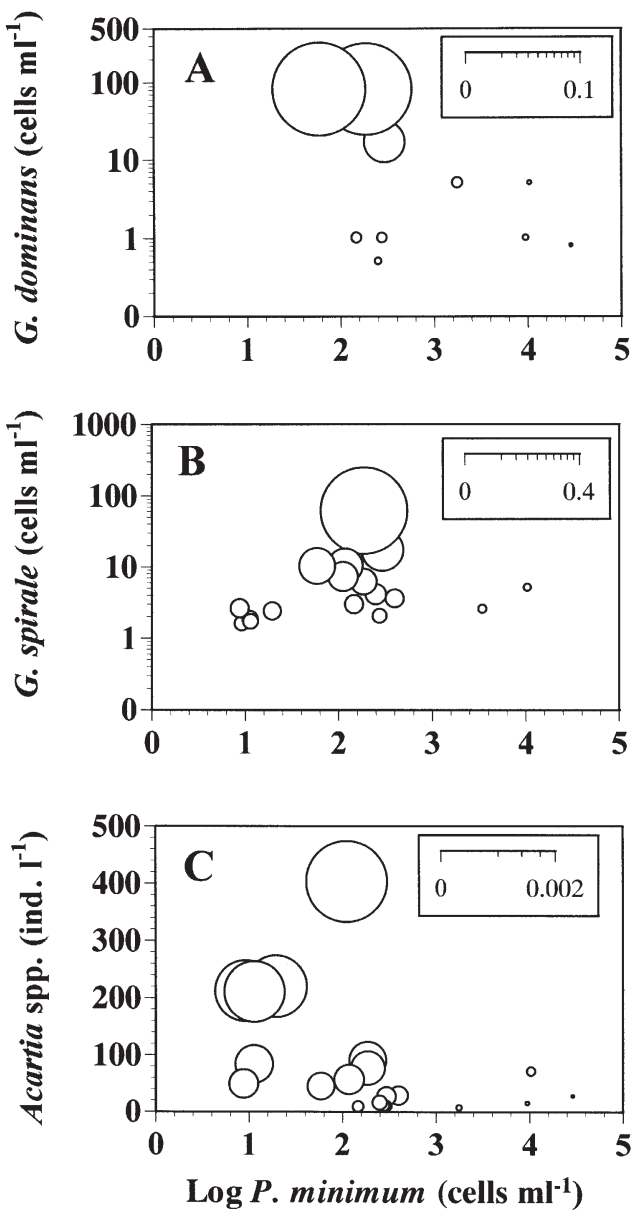

Fig. 7. (A) Gyrodinium dominans, (B) G. spirale, and (C) Acartia spp. Calculated grazing coefficients $\left(g, \mathrm{~h}^{-1}\right)$ on Prorocentrum minimum (see text for calculation). $\mathrm{N}=29$ divergens and P. crassipes may also not grow on the prey, because these Protoperidinium species did not grow on Prorocentrum balticum, which is similar to $P$. minimum in its size and shape (Jeong \& Latz 1994). Large ciliates Strombidinopsis sp. and Favella taraikaensis grew on the prey (Taniguchi \& Kawakami 1985, Jeong et al. 1999), while a small prostomatid ciliate Tiarina fusus did not grow (Jeong et al. 2002). Therefore, G. dominans and G. spirale are the only heterotrophic dinoflagellate grazers so far reported to grow on P. minimum.

\section{Growth and ingestion}

Gyrodinium dominans used in the present study has a higher maximum growth rate when feeding on Prorocentrum minimum $\left(1.13 \mathrm{~d}^{-1}\right)$ than for any other prey so far reported (Table 3 ), when corrected to $20^{\circ} \mathrm{C}$ using $Q_{10}=2.8$ (Hansen et al. 1997). However, the maximum growth rate of $G$. spirale on $P$. minimum $\left(0.79 \mathrm{~d}^{-1}\right)$ obtained in the present study was lower than that on the dinoflagellate Heterocapsa triquetra $\left(1.08 \mathrm{~d}^{-1}\right)$ (Hansen 1992). The cell volumes of G. dominans and G. spirale differ by strain, varying from ca. 1700 to $30000 \mu^{3}$ and from ca. 11500 to $16900 \mu^{3}$, respectively (Table 3). In general, the smaller strain of $G$. dominans or $G$. spirale has a higher maximum growth rate than the larger strain.

The maximum ingestion rate of Gyrodinium dominans on Prorocentrum minimum (1.2 ng grazer $^{-1} \mathrm{~d}^{-1}$ ) was lower than that on other phytoplankton prey so far reported (Table 3). However, the maximum ingestion

Table 2. Estimation of grazing impact by a Gyrodinium population or Acartia spp. populations on a Prorocentrum minimum population using the equations in Figs. 3 \& 4 in this study, the equation in Fig. 1 of Besiktepe \& Dam (2002) and the abundances of co-occurring P. minimum, Gyrodinium spp., and Acartia spp. obtained from water samples collected off Kwangyang in 2000 and Masan in 2003. $\mathrm{PmC}=$ P. minimum concentration; $\mathrm{GdC}=G$. dominans concentration; GdPIR = G. dominans population ingestion rate; $\mathrm{Gdg}=$ G. dominans grazing coefficient; $\mathrm{GsC}=$ G. spirale concentration; $\mathrm{GsPIR}=$ G. spirale population ingestion rate; Gsg = G. spirale grazing coefficient; $\mathrm{TGg}=$ total Gyrodinium grazing coefficient; $\mathrm{AD}=$ Acartia spp. density; APIR = Acartia spp. population ingestion rate; $\mathrm{Ag}=$ Acartia spp. grazing coefficient

\begin{tabular}{|c|c|c|c|c|c|c|c|c|c|c|}
\hline $\begin{array}{l}\text { PmC } \\
\left(\text { cells } \mathrm{ml}^{-1}\right)\end{array}$ & $\begin{array}{c}\text { GdC } \\
\left(\text { cells } \mathrm{ml}^{-1}\right)\end{array}$ & $\begin{array}{c}\text { GdPIR } \\
\left(\text { prey } \mathrm{ml}^{-1} \mathrm{~h}^{-1} \text { ) }\right.\end{array}$ & $\begin{array}{l}\text { Gdg } \\
\left(\mathrm{h}^{-1}\right)\end{array}$ & $\begin{array}{c}\mathrm{GsC} \\
\left(\text { cells } \mathrm{ml}^{-1}\right)\end{array}$ & $\begin{array}{c}\text { GsPIR } \\
\left(\text { prey } \mathrm{ml}^{-1} \mathrm{~h}^{-1}\right)\end{array}$ & $\begin{array}{l}\text { Gsg } \\
\left(\mathrm{h}^{-1}\right)\end{array}$ & $\begin{array}{l}\text { TGg } \\
\left(\mathrm{h}^{-1}\right)\end{array}$ & $\begin{array}{c}\mathrm{AD} \\
\left(\text { ind. } \mathrm{l}^{-1} \text { ) }\right.\end{array}$ & $\begin{array}{c}\operatorname{APIR}^{\mathrm{a}} \\
\left(\text { prey } \mathrm{ml}^{-1} \mathrm{~h}^{-1}\right)\end{array}$ & $\begin{array}{c}\mathrm{Ag} \\
\left(\mathrm{h}^{-1}\right)\end{array}$ \\
\hline 9 & 0 & 0 & 0 & 1.6 & 0.1 & 0.006 & 0.006 & 0.2104 & 0.01 & 0.0006 \\
\hline 12 & 0 & 0 & 0 & 1.7 & 0.1 & 0.007 & 0.007 & 0.2090 & 0.01 & 0.0006 \\
\hline 20 & 0 & 0 & 0 & 2.3 & 0.2 & 0.010 & 0.010 & 0.2181 & 0.01 & 0.0006 \\
\hline 60 & 80.0 & 3.8 & 0.066 & 10.0 & 2.3 & 0.040 & 0.106 & 0.0435 & 0.01 & 0.0001 \\
\hline 114 & 0 & 0 & 0 & 7.1 & 3.0 & 0.027 & 0.027 & 0.4013 & 0.11 & 0.0010 \\
\hline 190 & 80.0 & 11.9 & 0.065 & 60.0 & 39.2 & 0.231 & 0.296 & 0.0889 & 0.04 & 0.0002 \\
\hline 300 & 16.7 & 3.8 & 0.013 & 16.7 & 15.7 & 0.054 & 0.066 & 0.0252 & 0.02 & 0.0001 \\
\hline 1800 & 5.0 & 1.5 & 0.001 & 0 & 0 & 0 & 0.001 & 0.0054 & 0.01 & 0.0000 \\
\hline 3500 & 0 & 0 & 0 & 2.5 & 7.5 & 0.002 & 0.002 & 0.3994 & 0.72 & 0.0002 \\
\hline 10600 & 5.0 & 1.6 & 0 & 5.0 & 17.5 & 0.002 & 0.002 & 0.0696 & 0.13 & 0.0000 \\
\hline
\end{tabular}


Table 3. Comparison of growth, ingestion and clearance rates in the genus Gyrodinium. Rates are corrected to $20^{\circ} \mathrm{C}$ using $Q_{10}=$ 2.8 (Hansen et al. 1997). PDV = predator volume $\left(\times 10^{3} \mu \mathrm{m}^{3}\right)$; PYV = prey volume $\left(\times 10^{3} \mu \mathrm{m}^{3}\right) ; \mu_{\max }=$ maximum growth rate $\left(\mathrm{d}^{-1}\right)$; $I_{\max }=$ maximum ingestion rate $\left(\mathrm{ng} \mathrm{C}\right.$ predator $\left.{ }^{-1} \mathrm{~d}^{-1}\right) ; C_{\max }=$ maximum clearance rate $\left(\mu l\right.$ predator $\left.{ }^{-1} \mathrm{~h}^{-1}\right) ; \mathrm{SC}_{\max }=\operatorname{maximum}$ specific clearance rate $\left(\times 10^{5} \mathrm{~h}^{-1}\right) ; \mathrm{GGE}_{\max }=$ maximum gross growth efficiency $(\%) ; \mathrm{SS}_{\max }=$ maximum swimming speed $\left(\mathrm{mm} \mathrm{s}^{-1}\right)$; $\mathrm{DN}=$ dinoflagellate); DIA = diatom; RA = raphidophyte

\begin{tabular}{|c|c|c|c|c|c|c|c|c|c|c|}
\hline Predator & $\mathrm{PDV}^{\mathrm{a}}$ & Prey & PYV & $\mu_{\max }$ & $I_{\max }$ & $C_{\max }$ & $\mathrm{SC}_{\max }$ & $\mathrm{GGE}_{\max }$ & $\mathrm{SS}_{\max }$ & Source \\
\hline G. dominans & 2 & Prorocentrum minimum (DN) & 1.1 & 1.13 & 1.2 & 0.9 & 15.3 & 41 & 2.5 & This study \\
\hline G. dominans & 4 & Thalassiosira sp. (DIA) & 0.1 & 0.73 & & & & & & Nakamura et al. (1995) \\
\hline G. dominans & 4 & Heterocapsa triquetra (DN) & 1.9 & 0.54 & 2.3 & & 5.3 & & & Nakamura et al. (1995) \\
\hline G. dominans & 30 & Chattonella antiqua (RA) & 20.0 & 0.50 & 2.3 & & & & & Nakamura et al. (1992) \\
\hline G. spirale & 12 & Heterocapsa triquetra (DN) & 2.1 & 1.08 & $7.5^{\mathrm{b}}$ & 0.5 & 0.3 & 36 & & Hansen (1992) \\
\hline G. spirale & 17 & Prorocentrum minimum (DN) & 1.1 & 0.79 & 13.6 & 5.3 & 6.5 & 17 & 1.2 & This study \\
\hline
\end{tabular}

Table 4. Comparison of growth, ingestion and clearance rates of Gyrodinium spp. and other protists on Prorocentrum minimum. Rates are corrected to $20^{\circ} \mathrm{C}$ using $Q_{10}=2.8$ (Hansen et al. 1997). NC = naked ciliate; $\mathrm{TC}=$ tintinnid ciliate; HTD = heterotrophic dinoflagellate; other definitions as in Table 3

\begin{tabular}{|lccccc|}
\hline Predator & PDV & $\mu_{\max }$ & $I_{\max }$ & $C_{\max }$ & Source \\
\hline Gyrodinium dominans (HTD) & 2 & 1.13 & 1.2 & 0.9 & This study \\
Gyrodinium spirale (HTD) & 17 & 0.79 & 13.6 & 5.3 & This study \\
Tiarina fusus (NC) & 25 & $-0.006^{\mathrm{a}}$ & 2.0 & 0.2 & Jeong et al. (2002) \\
Polykrikos kofoidii (HTD) & 43 & -0.03 & 233 & 19.7 & Jeong et al. (2001) \\
Favella taraikaensis (TC) & 401 & & 296 & 122 & Taniguchi \& Kawakami (1985) \\
Strombidinopsis sp. (NC) & 560 & 1.17 & & \\
aThis rate is obtained at $19^{\circ} \mathrm{C}$ without. (1999) \\
\hline
\end{tabular}

rate of G. spirale on P. minimum (13.6 ng C grazer $^{-1}$ $\mathrm{d}^{-1}$ ) was higher than that on Heterocapsa triquetra (Hansen 1992). Unlike the maximum growth rate, the smaller strain of $G$. dominans or $G$. spirale has a lower maximum ingestion rate than the larger strain.

The maximum clearance rate of Gyrodinium spirale on Prorocentrum minimum $\left(5.3 \mu\right.$ grazer $\left.^{-1} \mathrm{~h}^{-1}\right)$ was much higher than that on Heterocapsa triquetra (Table 3). G. spirale might capture and ingest P. minimum more efficiently at low prey concentration than $H$. triquetra. The maximum clearance rate of $G$. dominans on $P$. minimum $\left(0.9 \mu\right.$ grazer $\left.^{-1} \mathrm{~h}^{-1}\right)$ was 5.9 times lower than that of $G$. spirale, while the cell volume of $G$. dominans used in the present study (ca. $600 \mu^{3}$ ), where the maximum volume-specific clearance rate was obtained, was 13.5 times smaller than that of $G$. spirale $\left(8100 \mu^{3}\right)$. The maximum swimming speed of $G$. dominans used in the present study $\left(2.5 \mathrm{~mm} \mathrm{~s}^{-1}\right)$ was 2.1 times higher than that of G. spirale $\left(1.2 \mathrm{~mm} \mathrm{~s}^{-1}\right)$. Therefore, the high swimming speed of $G$. dominans may increase the encounter rate between this grazer and $P$. minimum cells and thus enable the grazer to ingest a prey cell at a low prey concentration.
The maximum growth rate of Gyrodinium dominans on Prorocentrum minimum was comparable to that of Strombidinopsis sp. $\left(1.17 \mathrm{~d}^{-1}\right)$, but higher than that of Tiarina fusus or Polykrikos kofoidii on the same prey at the same temperature (Table 4). The maximum ingestion rate of $G$. spirale was much lower than that of Strombidinopsis sp. or Favella taraikaensis on the same prey, but much higher than $T$. fusus. Whereas $P$. kofoidii, Protoperidinium divergens, Protoperidinium crassipes, and Oblea rotunda, which have no positive growth on $P$. minimum, use tow filaments to anchor and subsequently engulfment or a pallium to envelop the prey cells, G. dominans, G. spirale, Strombidinopsis sp., and F. taraikensis, which have positive growth on $P$. minimum, directly engulf the prey cells. Direct engulfment may be a more efficient or low-energy-cost feeding mechanism for capturing small and flattened in shape $P$. minimum cells than deploying tow filaments.

\section{Grazing impact}

Grazing coefficients attributable to Gyrodinium dominans on co-occurring Prorocentrum minimum in 
the coastal waters off Kwangyang and Masan obtained in the present study were 0 to $0.066 \mathrm{~h}^{-1}$ (i.e. up to $6.4 \%$ of $P$. minimum populations were removed by a $G$. dominans population in $1 \mathrm{~h}$ ), while those for $G$. spirale were 0 to $0.231 \mathrm{~h}^{-1}$ (i.e. $39 \%$ of $P$. minimum populations were removed by a $G$. spirale population in $1 \mathrm{~h}$ ) (Table 2). The maximum grazing coefficient attributable to $G$. dominans plus $G$. spirale on P. minimum in the present study $\left(0.296 \mathrm{~h}^{-1}\right)$ was higher than that for the microzooplanktonic grazers on the same prey, measured in Chesapeake Bay, USA (ca. $0.17 \mathrm{~h}^{-1}$ ) (Johnson et al. 2003). Grazing coefficients attributable to G. dominans plus $G$. spirale at the P. minimum concentrations of 60 to 300 cells $\mathrm{ml}^{-1}$ ( 0.027 to $\left.0.296 \mathrm{~h}^{-1}\right)$ were much higher than those at the lower or higher P. minimum concentration $\left(0\right.$ to $\left.0.01 \mathrm{~h}^{-1}\right)$. In particular, grazing coefficients attributable to $G$. dominans plus $G$. spirale on $P$. minimum during the red tides dominated by the prey were $0.002 \mathrm{~h}^{-1}$ or $0.04 \mathrm{~d}^{-1}$ (i.e. $4 \%$ of $P$. minimum populations were removed by populations of $G$. dominans plus $G$. spirale in $1 \mathrm{~d}$ ). Therefore, the populations of G. dominans and $G$. spirale may have considerable grazing impact on $P$. minimum at the developing or declining stages of red tides dominated by $P$. minimum, but small grazing impact at the fully developed stage of the red tides. Grazing coefficients attributable to Acartia spp. on $P$. minimum were 0 to $0.001 \mathrm{~h}^{-1}$ or 0 to $0.02 \mathrm{~d}^{-1}$ (i.e. up to only $2.4 \%$ of $P$. minimum populations were removed by Acartia spp. populations in 1 d). The results of the present study suggest that Gyrodinium spp. may sometimes be much more effective grazers on $P$. minimum than Acartia spp.

Acknowledgements. We thank Seong Taek Kim, Yeong Du Yoo, Kyeong Ah Seong, Tae Hoon Kom, Jae Yoon Song, Nam Seon Kang, Jong Hyeok Kim, and Mi Seon Kim for technical support. This paper was funded by a NRL grant from MOST \& KISTEP (M1-0302-00-0068).

\section{LITERATURE CITED}

Besiktepe S, Dam HG (2002) Coupling of ingestion and defecation as a function of diet in the calanoid copepod Acartia tonsa. Mar Ecol Prog Ser 229:151-164

Borkman DG, Pierce RW, Turner JT (1993) Dinoflagellate blooms in Buzzards Bay, Massachusetts. In: Smayda TJ, Shimizu Y (eds) Toxic phytoplankton blooms in the sea. Elsevier, Amsterdam, p 211-216

ECOHAB (1995) The ecology and oceanography of harmful algal blooms. A national research agenda. Woods Hole Oceanographic Institute, Woods Hole, MA, p 1-66

Eppley RW, Harrison WG (1975) Physiological ecology of Gonyaulax polyedrum, a red tide water dinoflagellate of southern California. In: Locicero VR (ed) Proceedings of the First International Conference on Toxic Dinoflagellate Blooms. Massachusetts Science and Technology Foundation, Wakefield, MA, p 11-22
Fiala M, Kopczynska EE, Jeandel C, Oriol L, Vetion G (1998) Seasonal and interannual variability of size-fractionated phytoplankton biomass and community structure at station Kerfix, off the Kerguelen Islands, Antarctica. J Plankton Res 7:1341-1356

Frost BW (1972) Effects of size and concentration of food particles on the feeding behavior of the marine planktonic copepod Calanus pacificus. Limnol Oceanogr 17:805-815

Gallegos CL, Jordan TE (2002) Impact of the spring 2000 phytoplankton bloom Chesapeake Bay on optical properties and light penetration in the Rhode River, Maryland. Estuaries 25:508-518

Guillard RRL, Ryther JH (1962) Studies of marine planktonic diatoms. I. Cyclotella nana Hustedt and Detonula confervacea (Cleve) Grun. Can J Microbiol 8:229-239

Haigh R, Taylor FJR (1991) Mosaicism of microplankton communities on the northern Strait of Georgia, British Columbia. Mar Biol 110:301-314

Hansen PJ (1992) Prey size selection, feeding rates and growth dynamics of heterotrophic dinoflagellates with special emphasis on Gyrodinium spirale. Mar Biol 114: 327-334

Hansen PJ, Bjornsen PK, Hansen BW (1997) Zooplankton grazing and growth: scaling within the $2-2,000-\mu \mathrm{m}$ body size range. Limnol Oceanogr 42:687-704

Heinbokel JF (1978) Studies on the functional role of tintinnids in the Southern California Bight. I. Grazing and growth rates in laboratory cultures. Mar Biol 47:177-189

Holmes RW, Williams PM, Eppley RW (1967) Red water in La Jolla Bay, 1964-1966. Limnol Oceanogr 12:503-512

Hori Y, Miyahara K, Nagai S, Tsujino K and 5 others (1998) Relationships between the dominant phytoplankton and DIN:DIP ratios in Osaka Bay and Harima-Nada. Nippon Suisan Gakkaishi 64:243-248

Jeong HJ (1995) The interactions between microzooplanktonic grazers and dinoflagellates causing red tides in the open coastal waters off southern California. $\mathrm{PhD}$ thesis, University of California, San Diego

Jeong HJ (1999) The ecological roles of heterotrophic dinoflagellates in marine planktonic community. J Eukaryot Microbiol 46:390-396

Jeong HJ, Latz MI (1994) Growth and grazing rates of the heterotrophic dinoflagellate Protoperidinium spp. on red tide dinoflagellates. Mar Ecol Prog Ser 106:173-185

Jeong HJ, Shim JH, Lee CW, Kim JS, Koh SM (1999) Growth and grazing rates of the marine planktonic ciliate Strombidinopsis sp. on red-tide and toxic dinoflagellates. J Eukaryot Microbiol 46:69-76

Jeong HJ, Kim SK, Kim JS, Kim ST, Yoo YD, Yoon JY (2001) Growth and grazing rates of the heterotrophic dinoflagellate Polykrikos kofoidii on red-tide and toxic dinoflagellates. J Eukaryot Microbiol 48:298-308

Jeong HJ, Yoon JY, Kim JS, Yoo YD, Seong KA (2002) Growth and grazing rates of the prostomatid ciliate Tiarina fusus on red-tide and toxic algae. Aquat Microb Ecol 28:289-297

Johnson MD, Rome M, Stoecker DK (2003) Microzooplankton grazing on Prorocentrum minimum and Karlodinium micrum in Chesapeake Bay. Limnol Oceanogr 48:238-248

Lessard EJ (1991) The trophic role of heterotrophic dinoflagellates in diverse marine environments. Mar Microb Food Webs 5:49-58

Menden-Deuer S, Lessard E (2000) Carbon to volume relationships for dinoflagellates, diatoms, and other protist plankton. Limnol Oceanogr 45:569-579

Nakamura Y, Yamazaki Y, Hiromi J (1992) Growth and grazing of a heterotrophic dinoflagellate, Gyrodinium domi- 
nans, feeding on a red tide flagellate, Chattonella antiqua. Mar Ecol Prog Ser 82:275-279

Nakamura Y, Suzuki SY, Hiromi J (1995) Growth and grazing of a naked heterotrophic dinoflagellate, Gyrodinium dominans. Aquat Microb Ecol 9:157-164

Sherr E, Sherr B (2000) Marine microbes. An overview. In: Kirchman DL (ed) Microbial ecology of the oceans. WileyLiss, New York, p 13-46

Sournia A, Belin C, Berland B, Erard-Le Denn E and 5 others (1991) Noxious phytoplankton species on the coasts of France: from biology to prevention. Fremer Centre De Brest, Service Documentation Publication, Plouzane

Stoecker DK, Guillard RRL, Kavee RM (1981) Selective predation by Favella ehrenbergii (Tintinnida) on and among dinoflagellates. Biol Bull 160:136-145

Strathmann RR (1967) Estimating the organic carbon content of phytoplankton from cell volume or plasma volume. Limnol Oceanogr 12:411-418

Strom SL, Buskey EJ (1993) Feeding, growth, and behavior of

Editorial responsibility: Evelyn \& Barry Sherr (Contributing Editors), Corvallis, Oregon, USA the thecate heterotrophic dinoflagellate Oblea rotunda. Limnol Oceanogr 38:965-977

Taniguchi A, Kawakami R (1985) Feeding activity of a tintinnid ciliate Favella taraikaensis and its variability observed in laboratory culture. Mar Microb Food Webs 1:17-34

Tillmann U, Reckermann M (2002) Dinoflagellate grazing on the raphidophyte Fibrocapsa japonica. Aquat Microb Ecol 26:247-257

Trigueros JM, Orive E (2000) Tidally driven distribution of phytoplankton blooms in a shallow, macrotidal estuary. J Plankton Res 22:969-986

Watras CJ, Garcon VC, Olson RJ, Chishom SW, Anderson DM (1985) The effect of zooplankton grazing on estuarine blooms of the toxic dinoflagellate Gonyaulax tamarensis. J Plankton Res 7:891-908

Yallop ML (2001) Distribution patterns and biomass estimates of diatoms and autotrophic dinoflagellates in the NE Atlantic during June and July 1996. Deep-Sea Res 48: 825-844

Submitted: March 19, 2004; Accepted: May 11, 2004 Proofs received from author(s): September 25, 2004 